\title{
THE LIMITED OPERATION OF THE LIMITATIONS CLAUSE
}

\author{
TIMOTHY J. CHRISTIAN'
}

\begin{abstract}
This paper examines the operation of s. I of the Charter of Rights and Freedoms in three types of cases: first, those where there is a "direct collision" between legislative objectives and Charter guarantees; second, those involving the seemingly paradoxical limitation of the "self-limiting" rights and freedoms; and third, those where "unqualified" rights and freedoms are being defined. In its evolving analysis of the Charter the Supreme Court of Canada has approached each of these cases differently and there is now enough material to warrant a review of what, at first sight, might seem to be a very narrow topic.
\end{abstract}

\section{THE LEGITIMACY OF LEGISLATIVE OBJECTIVES}

Many commentators predicted that s. 1 would apply in every case where it was shown that a Charter right or freedom had been diminished. It was expected that in all such cases the state would have an opportunity to justify the statute or administrative action - to prove that it was a reasonable limit, prescribed by law and demonstrably justified in a free and democratic society. In fact, this has not happened. While it is clear that the burden of justifying a limit on a constitutional right or freedom lies upon the party claiming its benefit ${ }^{3}$ it is also clear from recent decisions that the state may not have an opportunity to justify all legislation or administrative actions which are inconsistent with constitutional guarantees. Most importantly, it appears that $\mathrm{s}$. 1 will not be reached where there is a direct collision between the purpose of an impugned statute and the purpose of a constitutional right or freedom. This may be seen most clearly in The Attorney General of Quebec v. Quebec Association of Protestant School Boards ${ }^{4}$ where, in a per curiam judgment, the Supreme Court of Canada decided that a Quebec statute, Bill 101, which restricted English language instruction in the schools, could not be justified because it was in direct collision with the language guarantee in s. 23 of the Charter. The Court said: ${ }^{5}$

The provisions of . . Bill 101 collide directly with those of s. 23 of the Charter, and are not limitations which can be legitimized by s. I of the Charter. Such limitations cannot be

1. Dean, Faculty of Law, University of Alberta. A version of this paper was presented at Judge's Day at the Annual Meeting of the Canadian Bar Association, in Edmonton, in August, 1986.

2. Section 1 provides as follows:

The Canadian Charter of Rights and Freedoms guarantees the rights and freedoms set out in it subject only to such reasonable limits prescribed by law as can be demonstrably justified in a free and democratic society.

3. This point was conclusively settled by the Supreme Court of Canada in its judgment in Hunter v. Southam where Dickson C.J.C. said:

The phrase "demonstrably justified" puts the onus of justifying a limitation on a right or freedom set out in the Charter on the party seeking to limit. [1984] 2S.C.R. 145, see also R. v. Oakes (1986) 65 N.R. 87 at 126 (S.C.C.).

4. (1985) 9 C.R.R. 133. At least two commentators dismissed the approach of the Supreme Court in this case as aberrant. P.W. Hogg was of the view that:

It seems to me highly undesirable, especially at this early stage in the exegesis of the Charter, to introduce a priori and unpredictable limitations on the scope of s. 1 . Constitutional Law of Canada, (2nd ed. 1985) 684.

See also [1985] 7:63 Sup. Ct. L. Rev. at 127.

5. Id. at 151 . 
exceptions to the rights and freedoms guaranteed by the Charter or amount to amendments of the Charter. [Emphasis added.]

This passage contemplated that a statute could not receive $s$. 1 consideration if it were an "exception" to the rights and freedoms guaranteed by the Charter. The Court reasoned that treating a directly colliding statute as a justifiable limitation would be tantamount either to amending or overriding one of the Charter's provisions in blatant disregard of the stipulated procedure. ${ }^{6}$ The Court was of the view that s. 23 had been included in the Charter precisely to invalidate Bill 101. In those circumstances Bill 101 could not "... possibly have been regarded by the framers of the Constitution as coming within such reasonable limits prescribed by law as can be demonstrably justified in a free and democratic society." Therefore, the limits imposed by Bill 101 were not ". . . legitimate limits within the meaning of $\mathrm{s.} 1$ of the Charter. ..." [emphasis added]

If the Court had based its judgment solely on the extraordinary drafting history of s. 23 of the Charter, in light of Bill 101, the decision might not be that portentous. However, the Court went on to rationalize its decision by giving an example to illustrate the principle it was invoking to preclude the operation of $5.1:^{9}$

An Act of Parliament or of a Legislature which, for example, purported to impose the beliefs of a State religion would be in direct conflict with s. 2(a) of the Charter, which guarantees freedom of conscience and religion, and would have to be ruled of no force or effect without the necessity of even considering whether such legislation could be legitimized by $\mathrm{s} .1$.

This statement is very significant because it contemplates a range of cases in which s. 1 can be completely avoided. By characterizing a statute as an "illegitimate limit" upon, or "exception" to, or case of "direct collision" with, a Charter guarantee, a Court could preclude reference to s. 1 .

This issue was next addressed by Wilson $J$. in her concurring judgment in Regina v. Big $M$ Drug Mart ${ }^{10}$ where she invoked the approach taken in Quebec Protestant School Boards. She held that the Sunday trading prohibition in the Lord's Day Act curtailed religious freedom and was precisely the sort of legislative target at which the Charter guarantee of freedom of conscience and religion was aimed. Therefore, she rejected the Government's attempt to justify the legislation, reiterating that it had been:"

made clear in Quebec Protestant School Boards, supra. that legislation cannot be regarded as embodying legitimate limits within the meaning of $s$. 1 where the legislative purpose is precisely the purpose at which the Charter right is aimed. [Emphasis added.]

The Lord's Day Act prohibition against Sunday trading was not a "legitimate limit" because it was designed to secure Sunday observance and, thereby, promote Christian religious practices. This was not a mere

6. To amend or override a Charter guarantee legislators would have to use the mechanisms expressly provided (i.e. s. 33 of the Charter, or Part V of the Constitution Act, 1982) and could not rely on s. 1 as a substitute.

7. Id. at 148 .

8. Id. at 148 .

9. Id. at 151 .

10. (1985) 13 C.R.R. 64.

11. Id. at 117. 
limitation of religious freedom but the antithesis of it. The purpose of the Lord's Day Act was similar to that of the hypothetical statute given as an example of legislation which could not reach s. 1 in Quebec Protestant School Boards - the imposition of the beliefs of a state religion.

The majority in Regina v. Big $M$ Drug Mart ${ }^{12}$ took a slightly different tack. Dickson C.J.C. did not speak of "legitimate limits" or "exceptions" or "direct collisions" but, in a similar vein, ruled that ". . . not every government interest or policy objective is entitled to s. 1 consideration. ..."'13 He observed that: ${ }^{14}$

principles will have to be developed for recognizing which government objectives are of sufficient importance to warrant overriding a constitutionally protected right or freedom.

It was only after a ". . . sufficiently significant government interest . . " had been ". . . recognized . . " that the court could move on to consider whether the means chosen to attain that end were reasonable. ${ }^{15}$ Dickson C.J.C. concluded that in this case it was unnecessary to decide whether s. 1 could validate the Lord's Day Act because the purpose of the Act was to compel religious observance - a legislative policy objective that was itself not entitled to $s .1$ consideration. ${ }^{16}$ It appears from these passages that Dickson C.J.C. considered the assessment of the ". . . government interest or policy objective ..." to be a condition precedent to further consideration of a statutory scheme under s. 1.

In $R$. v. Oakes ${ }^{17}$ Dickson C.J.C. again emphasized the assessment of the legislative objective, describing it as the first of two "central criteria" which must be satisfied to demonstrate that a limit on a Charter right was justified: $:^{18}$

First, the objective, which the measures responsible for a limit on a Charter right or freedom are designed to serve, must be "of sufficient importance to warrant overriding a constitutionally protected right or freedom": $R$. v. Big $M$ Drug Mart. The standard must be high in order to ensure that objectives which are trivial or discordant with the principles integral to a free and democratic society do not gain s. 1 protection. It is

12. (1985) 13 C.R.R. 64.

13. Id. at 110 .

14. Id. at 110 .

15. Id. at 110 .

16. Dickson C.J.C. simply asserted this proposition in the following terms:

The characterization of the purpose of the Act as one which compels religious observance renders it unnecessary to decide the question of whether $\mathrm{s} .1$ could validate such legislation whose purpose was otherwise or whether the evidence would be sufficient to discharge the onus upon the appellant to demonstrate the justification advanced. Id. at 110 .

17. [1986] i S.C.R. 103, (1986) 65 N.R. 87 (S.C.C.).

18. Id. at 138-39. Under the second arm of this analysis Dickson C.J.C. developed the following three pronged "proportionality test" for determining whether legislative means are reasonable and demonstrably justified:

First, the measures adopted must be carefully designed to achieve the objective in question. They must not be arbitrary, unjust or based on irrational considerations. In short, they must be rationally connected to the objective. Second, the means, even if rationally connected to the objective in this first sense, should impair "as little as possible" the right or freedom in question: R. v. Big M Drug Mart. Third, there must be a proportionality between the effects of the measures which are responsible for limiting the Charter right or freedom, and the objective which has been identified as of "sufficient importance". Id. at 139. 
necessary, at a minimum, that an objective relate to concerns that are pressing and substantial in a free and democratic society before it can be characterized as sufficiently important.

Second, once a sufficiently significant objective is recognized, then the party invoking s. 1 must show that the means chosen are reasonable and demonstrably justified.

In this portion of his judgment Dickson C.J.C. reinforced the notion that not all governmental objectives could qualify for treatment under the balancing criteria of s. 1. Objectives that were ". . . trivial or discordant with the principles integral to a free and democratic society ..." did not deserve the protection of s. 1. Dickson C.J.C. was of the view that the objective of protecting society from the "... grave ills associated with drug trafficking ..." was of sufficient importance, in certain circumstances, to warrant overriding a constitutionally protected right or freedom. Indeed, as far as he was concerned, the magnitude of the problem was such that the objective was self-evidently of sufficient importance to command further consideration under s. $1 .^{19}$

In $R$. v. Edwards Books and Art Ltd. ${ }^{20}$ Dickson C.J.C. repeated the Oakes criteria for establishing that a limit is reasonable and demonstrably justified in a free and democratic society:21

First, the legislative objective which the limitation is designed to promote must be of sufficient importance to warrant overriding a constitutional right. It must bear on a "pressing and substantial concern.' Second, the means chosen to attain those objectives must be proportional or appropriate to the ends.

He went on to decide that the Retail Business Holidays Act, which required certain retail premises to close on Sundays, was aimed at a "... pressing and substantial concern ..."22 and, only after having made this finding, considered whether the legislative means were proportionate to the objective.

In the developing analysis of the Charter it is clear that all legislation is not capable of reaching the balancing mechanism in s. 1. Questions about whether there is a rational connection between legislative means and legislative objectives, or whether the means are the least intrusive, or whether the effects of the means are proportional to the objective, will not be reached if the legislative objective itself is illegitimate. In order to qualify for consideration under s. 1, legislative objectives must cross two hurdles: first, they must not directly collide with the purpose of a constitutional guarantee, or stated somewhat differently, they must not be discordant with the principles integral to a free and democratic society; second, they must be of sufficient importance to warrant overriding a constitutional guarantee and, at a minimum, must bear on a pressing and

19. Ultimately, he held that there was ". . . no rational connection between the basic fact of possession [of a small quantity of narcotic] and the presumed fact of possession for the purpose of trafficking." Therefore, the presumption in $\mathbf{s .} 8$ of the Narcotics Control Act was "overinclusive" and "irrational" and could not be justified.

20. (1986) unreported (S.C.C.).

21. Id. at VII.

22. The pressing and substantial concern was the trend toward wide scale store openings which would make a common pause day impossible. Dickson C.J.C. said:

I regard as self-evident the desirability of enabling parents to have regular days off from work in common with their child's day off from school, and with a day off enjoyed by most other family and community members. 
substantial concern. The first hurdle may, for convenience, be called the "direct collision" exception; the second the "sufficient importance" exception. Those governmental objectives which have been approved under these criteria include protecting the public from drug trafficking and legislating a common pause day. On the other hand, requiring Sunday observance and denying access to instruction in the English language, have been held to be illegitimate objectives.

It is not clear how many legislative objectives will fail to qualify for treatment under s. 1. From the early cases it would seem that few legislative objectives could fail to pass the "sufficient importance" threshold by being declared to be too trivial or insignificant to advance to s. 1. Most legislation is enacted to deal with some perceived social problem and while it might not be successfully argued that the mere existence of legislation is indicative of a pressing and substantial concern, not much more may be required. In both cases to date where this has been at issue, the Chief Justice has held the legislative objective to be self-evidently of sufficient importance to proceed further. If protecting the public against drug trafficking and establishing a common pause day are self-evidently of such pressing and substantial concern as to warrant overriding a constitutional guarantee, it is difficult to imagine many subjects addressed by modern legislators which would not pass this minimal requirement and qualify for further consideration under $\mathrm{s} .1 .^{23}$

It is more difficult to predict what sort of impact the "direct collision" exception will have for it requires a more difficult and subjective, one might almost say intuitive, inquiry. The "direct collision" exception operates when there is such a profound conflict between the purpose of a statute and the purpose of a constitutional guarantee that there is perceived to be a complete denial rather than a mere limitation of a right. It is necessary to distinguish legislation that totally derogates or debases a right from legislation that only circumscribes or narrows the area of operation of a right. That legislation which narrows or circumscribes can go on to be considered under the balancing tests - that which directly collides cannot.

Obviously there can be degrees of inconsistency between the purpose of a statute and the purpose of a constitutional guarantee. A statute which prohibited Sunday trading was held to directly collide with the guarantee of freedom of conscience and religion because it was enacted for the purpose of securing Sunday observance. On the other hand, a statute which also prohibited Sunday trading, but for the purpose of securing a common pause day, was held not to collide with the purpose of the constitutional guarantee, even though it may have had the effect of

23. In Jones v. The Queen [1986] 2 S.C.R. 284 (S.C.C.) at 297 LaForest J. held, without direct evidence, that "... education today is a matter of prime concern to government everywhere." He required “. . . no further demonstration ..." than a quotation from Brown v. Board of Education of Topeka 347 U.S. 483 (1954) to satisfy himself that the interest of the Province of Alberta in educating the young was ". . . compelling. ..." He ultimately held that the requirement that a person who gives instruction at home or elsewhere ". . . have that instruction certified as being efficient . . ." was a reasonable limitation upon freedom of religion in a free and democratic society. 
limiting some persons' religious freedom. ${ }^{24}$ Because it limited rather than denied freedom of conscience and religion the operation of the limiting mechanism contained in the pause day statute could be examined and tested under the balancing criteria in s. 1 . Was it rationally connected to the objective? Did it employ the least intrusive means? Were the effects of the means proportionate to the objective? All of these questions could be sensibly put. However, the outright denial of the right contemplated by the Sunday observance legislation could not be assessed according to criteria designed to measure the reasonableness of a limitation precisely because it was not an attempt at limitation - but an attempt to deny that the right existed.

In order to understand the operation of the "direct collision" exception it is necessary to distinguish between statutory purpose and statutory effect. The observed effects of a statute may give rise to an inference about its purpose and, on examination, it may be determined that the observed effects were the deliberate result of the statutory purpose. In such case there is congruence between purpose and effect. However, characterizing the purpose of a statute might not be determinative of the effects of the means used to secure the purpose. The effects might be unanticipated, unintended, and fortuitous and could even be incongruous with the statutory purpose. Thus, a statute which has a benign constitutional objective may, in its operational or administrative aspect, authorize or give rise to an unconstitutional effect. If the effect of the measure is disproportionate to the importance of the objective, the measure will be declared unconstitutional. If the attainment of the objective is of sufficient importance the limitation of a constitutional guarantee effected by the measure may not be disproportionate. For example, the importance of preserving public health in the face of an epidemic might be of sufficient importance to make proportionate a measure which prohibited public gatherings - including religious services - and thereby limited the freedom of conscience and religion..$^{25}$ The purpose of the legislation would be to preserve public health; the means employed would include prohibiting public gatherings; the effect would be that freedom of conscience and religion would be limited. Assuming that the purpose did not collide with a constitutional guarantee, the question would be whether the effects of the measure employed to secure the objective were disproportionate. This would involve a close examination of the operational mechanism and the facts of particular cases where the prohibition was applied.

The "direct collision" exception is concerned with conflicts in purpose between constitutional guarantees and statutory objectives. It is not designed to deal with conflicts between a constitutional purpose and a statutory effect. Invalid, or unconstitutional purposes are caught by the "direct collision" exception - overreaching legislation giving rise to disproportionate effects is caught by the balancing mechanism in $\mathrm{s} .1$. The

24. Those persons who wish to worship on a day other than the common pause day may have difficulty doing so because of the need to open their businesses and compete with Sundayobserving owners of businesses. The same may be said of employees whose Sabbath is not Sunday and are required to work on their Sabbath.

25. Such a provision may be found in public health statutes. For example, see the Ontario Public Health Act, R.S.O. 1980, c. 409, s. 95(2). 
"direct collision" exception is concerned with purpose - the "propor-
tionality test" 26 relates to effect."

The "direct collision" exception requires a ranking of the political and moral values of life in a free and democratic society. Another example may be of assistance. Imagine two statutes which imposed schemes of censorship - the first directed at eliminating obscenity from commercial films and the second aimed at removing commentary critical of the federal government from television news. Both statutes would have a negative impact on the freedom of expression. The purpose of eliminating obscenity would probably qualify as a legitimate governmental objective: protecting the public, and particularly the young, for obscenity has long been considered a proper governmental objective; ${ }^{28}$ it is not a trivial objective; the elimination of obscenity is not discordant with the principles of a free and democratic society; the scheme is an attempt to limit rather than deny

26. The components of the "proportionality test" are set out by Dickson C.J.C. in R. v. Oakes in n. 18 supra.

27. In her dissenting judgment in Jones v. The Queen [1986] 2 S.C.R. 284 (S.C.C.) Wilson J. employed this analysis. She first held that the purpose of the School Act, R.S.A. 1980, c. S-3 was "... to ensure that children receive an adequate education...." (id. at 313) She reasoned that Jones' complaint that the statutory machinery requiring certification infringed his freedom of religion was ". . . effects-based rather than purpose-based" (id. at 313) Ultimately she determined that the legislative scheme did not have a substantial impact on Jones' belief in God and did not infringe his freedom of religion. However, she went on to say in obiter dicta that if the Act did infringe freedom of conscience and religion, it could not be saved by s. 1 . Even though the purpose was constitutionally benign the Province had not proved that the means employed to attain the objective were the "... least drastic means of ensuring ..." that children were receiving efficient instruction. (id. at 313).

28. In R. v. Red Hot Video Ltd. (1985) 18 C.C.C. (3d) 1 (B.C.C.A.), the British Columbia Court of Appeal considered whether the obscenity provision of the Criminal Code, s. 159, violated freedom of expression. It was conceded that the video tapes in question were obscene and the Court had no difficulty in upholding the statutory objective. Nemetz C.J.B.C. observed that

For centuries democratic societies have set certain limits to freedom of expression. Libel and slander are two such limitations. Obscenity is also a limitation. (id. at 5 )

He also went to quote the following passage from the judgment of Dickson J., as he then was, in R. v. Great West News Ltd., Mantell and Mitchell [1970] 4 C.C.C. 307 at 309:

... all organized societies have sought in one manner or another to suppress obscenity. The right of the state to legislate to protect its moral fibre and well-being has long been recognized, with roots deep in history. It is within this frame that the Courts and Judges must work. 
the freedom of expression..$^{29}$ Even though the objective might be constitutionally acceptable, it would be necessary to examine the effects of the scheme under the balancing criteria of the proportionality test. Is there a rational connection between the objective of eliminating obscenity and the means chosen to achieve this objective? Have the least intrusive means been chosen? Are the effects of the scheme proportionate to the objective? The constitutionality of the scheme would depend on its impact.

In contrast, it could be predicted, based on a conventional ranking of political and moral values, ${ }^{30}$ that the statute to censor political opposition to the government would not be treated in the same way. Eliminating political opinions adverse to the government would directly collide with the purpose of free expression in a free and democratic society. The system is premised on the free exchange of political ideas - no government is immune from vigorous criticism - and an attempt to stifle criticism would strike at an integral principle of life in a free and democratic society. Such a scheme would not qualify for consideration under the balancing criteria of the proportionality test. Since the purpose is offensive it would not be necessary to examine effects.

It should also be observed that constitutionally benign effects could not rescue an unconstitutional purpose. Even though the Lords' Day Act may have had the socially beneficial effect of creating a common pause day, ${ }^{31}$ this could not preclude or minimize the consequences of the "direct collision" between the purpose of the statute and the purpose of the constitutional guarantee of freedom of conscience and religion. That is why the characterization of purpose must be separated from the measurement of effect.

29. The statute under consideration in the decision of the Ontario Court of Appeal in Ontario Film Video Appreciation Society and Ontario Board of Censors (1986) 5 D.L.R. (4th) 766 (Ont. C.A.) is an example of a blanket censorship power which denied rather than limited freedom of expression. The question was whether s. 3(2)(a) of the Theatres Act, R.S.O. 1980, c. 498 was in violation of the Charter guarantee of freedom of expression. The section provided as follows:

The board shall have the power,

(a) to censor any film and, when authorized by the person who submits film to the Board for approval, remove by cutting or otherwise from the film any portion thereof that it does not approve of for exhibition in Ontario.

The Court held that the section was violative of free expression and that it could not be salvaged by $\mathrm{s}$. 1 because it allowed

... for the complete denial or prohibition of the freedom of expression in this particular area and sets no limits on the Ontario Board of Censors. It clearly sets no limit, reasonable or otherwise, on which an argument can be mounted that it falls within the saving words of s. 1 of the Charter: "subject only to such reasonable limits prescribed by law". (id. at 767).

Presumably, if the statute had authorized censorship only of "obscene" films, or if it set out other limits on the Board's authority, these limits would have been considered under the balancing criteria in the proportionality test. The problem here was the direct collision between the constitutional guarantee of free expression and the statutory purpose of allowing any film to be censored for any reason - thus authorizing a complete denial of free expression.

30. The conventional approach would be to rank the political liberties necessary for a free and democratic society ahead of other liberties.

31. In R. v. Edwards Books and Art Ltd. Dickson C.J.C. said that a common pause day was selfevidently a socially desirable end. See $\mathrm{n} .22$ supra. 
Far from being an arcane exception to the application of s. 1, turning on the peculiar facts of Quebec Protestant School Boards, the "direct collision" approach has proven to be a fundamentally important fetter on the power of the state to justify legislative action which conflicts with Charter guarantees. If the limitations clause could justify the denial of rights and freedoms, the express override provision in s. 33 would be redundant. Where there is a direct conflict in purpose s. 33 must be employed - with the attendant political risks for a government which seeks to deprive citizens of constitutional rights or freedoms. As guardians of the constitution the courts have shown themselves to be alert to attempts to disguise the denial of rights as mere limitations of rights.

\title{
II. SELF-LIMITING RIGHTS AND FREEDOMS
}

The application of $\mathbf{s .} 1$ is particularly difficult in relation to the selflimiting rights and freedoms. Those are the guarantees which are not expressed absolutely but conditionally, in the sense that they contain builtin, flexible criteria for limiting their scope. For example, s. 8 does not guarantee the right to be secure against any "search or seizure" but only against "unreasonable search or seizure". If a search were found to be "unreasonable" would the Court have to decide, employing s. 1, whether the "unreasonable" search was, nevertheless, "reasonable" in a free and democratic society?

If it were determined that the purpose of a statute were to direct unreasonable searches that statute would be in "direct collision" with the constitutional right to be secure from unreasonable search and seizure and could not qualify for further consideration under the balancing criteria in the proportionality test. This approach was hinted at in Hunter v. Southam Inc. ${ }^{32}$ where Dickson C.J.C. determined that s. 10(1) and (3) of the Combines Investigation Act were "inconsistent with the Charter and of no force or effect.' He said: ${ }^{33}$

\begin{abstract}
Without appropriate safeguards legislation authorizing search and seizure is inconsistent with s. 8 of the Charter. As I have said, any law inconsistent with the provisions of the Constitution is, to the extent of the inconsistency, of no force or effect. I would hold s. 10(1) and (3) of the Combines Investigation Act to be inconsistent with the Charter and of no force and effect, as much for their failure to specify an appropriate standard for the issuance of warrants as for their designation of an improper arbiter to issue them.
\end{abstract}

The problem with the legislation was that it permitted searches and seizures to be made under the authority of warrants that had been issued, without reference to appropriate standards, by a person who was not impartial. The purpose of the statute directly collided with the purpose of the constitutional right to be secure from unreasonable search and seizure. The Court did not determine whether the statute could, nevertheless, be justified under S. 1. Dickson C.J.C. said that the appellants had made ${ }^{34}$

.. no submissions capable of supporting a claim that even if the searches under s.10(1) and (3) are "unreasonable" within the meaning of s. 8, they are nevertheless a reasonable limit, demonstrably justified in a free and democratic society, on the right set out in s. 8. It is, therefore, not necessary to consider the relationship between s. 8 and s. 1 . I leave to another day the difficult question of the relationship between those two sections and,

32. (1984) 9 C.R.R. 355 (S.C.C.).

33. Id. at 374.

34. Id. at 374. 
more particularly, what further balancing of intersts, if any, may be contemplated by s. 1 , beyond that envisaged by s. 8 . [Emphasis added.]

It is difficult to imagine what sort of arguments might have been "capable" of supporting a submission that a statute which had the purpose of authorizing unreasonable searches and seizures was nevertheless a reasonable limit in a free and democratic society. As the cases above indicate, if there is a direct collision between the purpose of a statute and the purpose of a Charter guarantee, there is nothing to measure under the proportionality test. A statute denying the right to be secure from unreasonable search and seizure does not merely limit enjoyment of the right - it completely impairs it.

This was essentially the approach taken by the Ontario Court of Appeal in R. v. Noble ${ }^{35}$ where Martin J.A. held that the provisions of s. 10(1)(a) of the Narcotic Control Act, which authorized searches of private dwellings under writs of assistance, collided with $\mathbf{s .} 8$ of the Charter and could not be saved by reference to $\mathrm{s.} 1:^{36}$

In my view, the provisions of s. 10(1)(a) authorizing the search of a dwelling-house under a writ of assistance on their face collide with 5.8 of the Charter. [emphasis added]

Martin J.A. considered the possibility of further examining the section under the balancing criteria of s. 1 but, after citing the words of Dickson C.J.C. in Hunter v. Southam Inc., as quoted above, ${ }^{37}$ decided: $:^{38}$

... I would have great difficulty in concluding that the legislation is justifiable under $\mathrm{s.} 1$ as a reasonable limit prescribed by law....

This conclusion is also consistent with the approach the Supreme Court of Canada took in dealing with the application of s. 1 to s. 7 in Reference re Section 94(2) of the Motor Vehicle Act, R.S.B.C. 1979, c. 228. ${ }^{39}$ The majority held that $\mathbf{s .} 1$ may be used in extreme circumstances to justify a violation of s. 7. Lamer J. wrote that a deprivation of liberty in breach of the principles of fundamental justice could, in principle, be "... salvaged ..." if the authorities could demonstrate that the limit was saved under s. 1 . However he cautioned that ". . . administrative expediency ..." would succeed as a justification only in exceptional conditions such as ". . . natural disasters, the outbreak of war, epidemics and the like." 40

Wilson J. disagreed, holding that s. 1 could not be invoked once it had been found that the principles of fundamental justice had been violated in depriving a person of liberty. She said: ${ }^{41}$

... in my view a law which interferes with the liberty of the citizen in violation of the principles of fundamental justice cannot be saved by s. 1 as being either reasonable or justified. The concepts are mutually exclusive.

35. (1985) 14 D.L.R. (4th) 217 (Ont. C.A.).

36. Id. at 235 .

37. At n. 34 .

38. Id. at 240 . He nevertheless held that admitting the evidence obtained pursuant to the search would not bring the administration of justice into disrepute and refused to exclude it pursuant to s. 24(2).

39. [1986] 1 W.W.R. 481 (S.C.C.).

40. Id. at 509 .

41. Id. at 517 . 
Though the majority did not hold that the concepts were "mutually exclusive," and though it appears that a departure from the principles of fundamental justice can be saved under s. 1 , it also appears that such a departure could only rarely be justified..$^{42}$ If Lamer J. is followed, such an argument will succeed only in grave emergencies. In routine conditions, the dictates of administrative efficiency notwithstanding, s. 1 could not rescue a departure from the principles of fundamental justice.

It remains to be seen whether the Court will take a similar view of the application of s. 1 to the other self-limiting provisions. If it was not deterred by the logical difficulty of finding that, in principle, a violation of the principles of fundamental justice could be reasonable in a free and democratic society, it will not likely be put off by the apparently illogical question of whether an unreasonable search is reasonable. However, given the decision in Reference re Section 94(2) of the Motor Vehicle Act, R.S.B.C. 1979, c. 228 , it is likely that the Court will apply s. 1 to selflimiting provisions in only rare cases.

Support for this conclusion may be found in the decision of the Ontario Court of Appeal in Regina v. Metro News Ltd. ${ }^{43}$. Martin J.A. held that s. 159 of the Criminal Code, which created an absolute liability offence, and therefore deprived the accused of liberty contrary to the principles of fundamental justice, was not justified under s. 1. He was prepared to consider the application of $s .1$ because the accused was a corporation and not a natural person. Nevertheless, he was of the view that ${ }^{44}$

....s. 159(6) cannot be justified as a reasonable restriction of the constitutional right protected by $\mathrm{s} .7$ because it impairs that right more than is necessary to achieve the objective sought of relieving the Crown of the burden of proof with respect to guilty knowledge on charges of distributing obscene matter because of the alleged difficulty or virtual impossibility in the circumstances of discharging that burden.

If a departure from the principles of fundamental justice could not be justified even where it was virtually impossible for the Crown to discharge its burden of proving that a distributor had knowledge of the contents of material distributed, it is probably safe to predict that a deprivation of $\mathrm{s} .7$ rights will only rarely be salvaged under $\mathrm{s} .1$.

\section{UNQUALIFIED RIGHTS AND FREEDOMS}

In contrast to those rights and freedoms which are self-limiting, are those which are framed in unqualified, and apparently absolute terms. The fundamental freedoms in $\mathrm{s} .2$ provide the best example.

Everyone has the following fundamental freedoms:

(a) freedom of conscience and religion ...

The section does not limit the freedom to reasonable religious practices, or reasonable beliefs. The scope is unqualified and before s. 1 can be brought into play it is necessary to define the rights and freedoms. This

42. In Jones v. The Queen [1986] 2 S.C.R. 284 (S.C.C.) at 322, Wilson J. referred to her earlier judgment in Reference re Section 94(2) of the Motor Vehicle Act, R.S.B.C. 1979, c. 228 and "assumed" that she was wrong in her view that s. 1 could not save a statute which violated an individual's rights under $\mathrm{s} .7$.

43. (1987) 23 C.R.R. 77 (Ont. C.A.).

44. Id. at 94 . 
point was recognized by Wilson $\mathrm{J}$. in Operation Dismantle Inc. v. The Queen ${ }^{45}$ where she observed:

the rights under the Charter not being absolute, their content or scope must be discerned quite apart from any limitation sought to be imposed upon them by the government under s. 1 .

In the absence of an express limitation clause the approach to defining such a right would be different. The courts could be expected to cautiously define rights to avoid potential conflicts and extreme interpretations. For example, if "freedom of expression" were given an absolute meaning, the provisions in s. 159 of the Criminal Code which make it an offence to publish obscene material would have to be ruled unconstitutional as infringing the freedom of expression. In order to avoid such a result, the courts could be expected to narrow the definition of freedom of expression to exclude obscene expression. This would be similar to the approach of the United States Supreme Court which has held that ". . . obscenity is not within the area of protected speech or press." 45 If it followed the American approach, the Canadian court would be effectively amending the fundamental freedom to read that everyone has the freedom of expression - but not obscene publication.

In a system without an express limitation clause all such checks would have to be judicially created as part of the definition. In contrast, the method of limitation under the Charter is stated in s. 1. In the face of these express standards for balancing competing interests, the Canadian courts are not called on to invent narrow definitions to restrict the scope of unqualified rights and freedoms. At the stage of definition the rights and freedoms are to be broadly interpreted. To take the obscene publication example again: at the definition stage, freedom of expression would include the freedom to express any ideas at all, including obscene ideas. This is clearly consistent with the plain words of the Charter which do not qualify the term "expression" in any way. Provided publication could be characterized as expression it would come within the scope of the freedom..$^{47}$ The issue would then be whether the law prohibiting obscene publication could be justified under s. 1 and, assuming that the "sufficient importance" and "direct collision" hurdles could be passed, further consideration would follow under the proportionality test.

The words of $s .1$ demand that this balancing function be undertaken in a deliberate and open fashion, and not avoided by the adoption of narrow definitions that preclude the issue of justification. In the obscenity example, the harm from limiting the free expression of ideas must be balanced against the potential harm from the publication of obscene material. Section 1 gives the courts the task of arbitrating disputes between

45. [1985] 1 S.C.R. 441 at 489.

46. Ginsberg v. New York 390 U.S. 629 at 635 (1968) (U.S.S.C.) per Brennan J.

47. In Regina v. Metro News (1987) 23 C.R.R. 77 (Ont. C.A.) Martin J.A. observed;

Freedom of expression includes all forms of expression whether oral, written, pictorial, sculpture, music, dance or film: Re Ontario Film and Video Appreciation Society and Ontario Board of Censors (1983) 5 C.R.R. 373 at 379; affirmed (1984) 7 C.R.R. 129, and all phases from maker or originator through supplier, distributor, retailer, renter or exhibitor to receiver whether as a listener or a viewer: $R$. v. Videoflicks Ltd. et al. (1984) 9 C.R.R. 193 at 228. 
competing social and political values. This task cannot be avoided by defining problems out of existence.

\section{CONCLUSION}

As the foregoing cases demonstrate, resort to s. 1 is not automatic. The current position may be summarized as follows.

1. The process of definition must be distinct from the process of justification. A right or freedom is to be defined broadly and without regard to the factors that may be significant at the stage of justification. In the case of a "self limiting" right or freedom the same criteria that would be considered under the "proportionality test" may be read into the definition.

2. The purpose of an impugned statute must be compared with the purpose of the Charter right or freedom it is alleged to violate. If there is a prima facie conflict it is necessary to decide: (a) whether the statutory objective is of "sufficient importance" to permit a constitutional right or freedom to be limited; and if it is, (b) whether there is a "direct collision" between the objectives of the impugned statute and the purpose of the Charter right or freedom.

3. If the statutory objective is of "sufficient importance" and is not in "direct collision" with the Charter guarantee it is necessary to distinguish between "unqualified" and "self limiting" rights and freedoms. If the Charter guarantee under consideration is "self limiting" further reference to $\mathrm{s}$. 1 should only be undertaken in extraordinary circumstances.

4. If the impugned statute is considered further, it must be decided whether: (a) the means it employs are rationally related to the statutory objective; (b) the means are the least damaging to the Charter right or freedom; (c) the effects of the means are proportionate to the importance of securing the statutory objective in light of the fact that a Constitutional right or freedom is being limited. If the statute fails to satisfy any of these criteria it will be declared to be unconstitutional.

It is apparent from the preceding review that the Canadian courts have assumed an important role as guardians of the Constitution and it is obvious that they have resisted government efforts to diminish Charter rights and freedoms. While Canada has thus moved closer to the American model of government, it is worth noting in closing that there are two important differences in the roles of the Canadian and American courts in constitutional law. The Canadian courts have a different and broader function than their American counterparts. There is nothing in the American constitutional documents that compares with s. 1 or s. 52(1). In the United States the power of the courts to strike down unconstitutional legislation stemmed from the assertion of such authority by the courts themselves. It was not until thirty years after the Declaration of Independence that Chief Justice Marshall held that the American courts could strike down unconstitutional legislation. ${ }^{48}$ The legitimacy of this assertion of power has remained controversial ever since. ${ }^{9}$ In Canada the power of

48. Marbury v. Madison 5 U.S. (1 Cranch) 173.

49. See Ronald Dworkin, Law's Empire (1986) 355-58. 
the courts to strike down unconstitutional legislation is constitutionally affirmed in s. 52(1). While the American courts were never given express authority to rule on constitutional issues, the Canadian courts have a mandate to do so.

Finally, s. 1 blurs the distinction, implicit in the American Constitution, between the legislative and judicial role. It requires the Canadian courts to assess what the American courts are, in theory, to ignore - the essentially political arguments which would justify a departure from a constitutional value. The role of the Canadian judiciary is more expansive and overtly political than the American model would permit. 